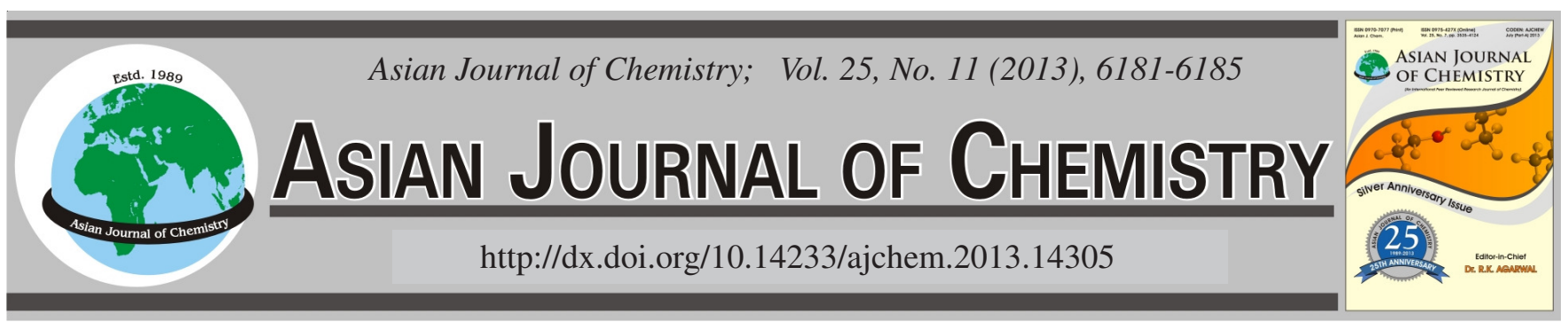

\title{
Spectrophotometric Determination of Acidity Constant of 1-Methyl-4-[4'-aminostyryl]quinolinium Iodide in Aqueous Buffer and Micellar Solutions in the Ground and Excited States
}

\author{
Farag M.A. Altalbawy* and El-Sayed A.M. Al-Sherbini
}

Department of Measurements and Environmental Applications, National Institute of Laser Enhanced Sciences, Cairo University, P.O. Box 12613, Giza, Egypt

*Corresponding author: E-mail: f_altalbawy@yahoo.com; elsayed@niles.edu.eg

(Received: 13 July 2012;

Accepted: 2 May 2013)

AJC-13430

\begin{abstract}
Electronic absorption and excitation spectra of 1-methyl-4-[4'-amino styryl]quinolinium iodide $\left(\mathrm{Q}-\mathrm{NH}_{2}\right)$ were measured in aqueous buffer and micellar solutions. The acid dissociation constants in ground and excited states, $\mathrm{pK}$ and $\mathrm{pK}$ *, were determined spectrophotometrically and amount for the aqueous solution to 3.24 and 1.19 , respectively and the $\mathrm{pK}$ and $\mathrm{pK}$ * for the $\left(\mathrm{Q}-\mathrm{NH}_{2}\right)$ in sodium dodecyl sulphate are 3.72 and -1.95 . The results indicated that the pks of the micellar solution is higher than that of the aqueous solution due to the concentration of protons at the micellar interface which suppress the protonation in the ground state. This reflects the large difference between the excited and the ground state dissociation constants of the micellar solution. The mechanism of the studied reactions is discussed.
\end{abstract}

Key Words: 1-Methyl-4-[4'-amino styryl]quinolinium iodide, Acidity constant, Spectrophotometric, Surfactant.

\section{INTRODUCTION}

Dye-surfactant interactions in aqueous buffered systems have been drawing interest of many researchers due to their industrial applications ${ }^{1}$. And aqueous micellar media are widely used in different areas of analytical chemistry and several reviews concerning their analytical applications have been published ${ }^{2-5}$. One important property of micelles is their ability to solubilize a wide variety of compounds which are insoluble or slightly soluble in water. The incorporation of a solute into micellar systems can lead to important changes in its molecular properties. Another important effect of micellar systems is that they can modify reaction rates and, to some extent, the nature of the products. Micelles can inhibit or accelerate reaction rates (by up to several orders of magnitude) and also shift equilibria (acid-base). Surfactants usually affect spectral parameters: the intensity and shifts in the absorption bands can be increased and shifts in the absorption maxima of reagents are observed ${ }^{6}$. Micelles can affect the apparent $\mathrm{pK}_{\mathrm{a}}$ values of the reagents due to a combination of electrostatic and microenvironment effects of the micelle $e^{6,7}$. Moreover, the acid-base equilibrium involved in these systems is also influenced by surfactants ${ }^{8-11}$. The acid dissociation constants (i.e., $\mathrm{pK}_{\mathrm{a}}$ values) can be a key parameter for understanding and quantifying chemical phenomena such as reaction rates, biological activity, biological uptake, biological transport and environmental fate ${ }^{12}$.
Merocyanine dyes are well known as solvatochromic and photoreactive compounds which are also sensitive to the medium acidity ${ }^{13}$. Due to these properties they are potentially useful in many areas such as solar energy conversion ${ }^{14,15}$, photosensitizers ${ }^{16}$, phototherapy ${ }^{17}$, in laser doublers and as liquid crystals ${ }^{18}$. Merocyanine dyes are also useful as electrochromic compounds for membrane potentials and highvoltage sensitivity ${ }^{19,20}$.

In the present article, we applied the physical constraints approach to determine the acidity constant of 1-methyl-4-[4'aminostyryl]quinolinium iodide $\left(\mathrm{Q}=\mathrm{NH}_{2}\right)($ Chart 1$)$ in water, water-sodium dodecyl sulfate in grouned and excited states.

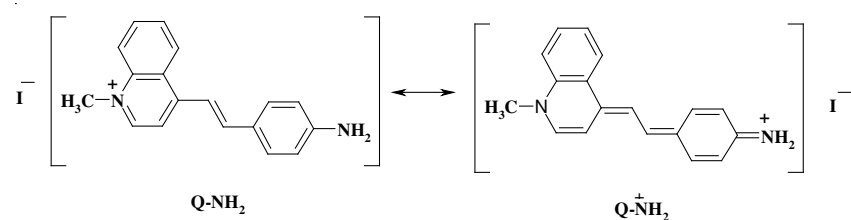

Chart 1. 1-Methyl-4-[4'-amino styryl]quinolinium iodide, $\left(\mathrm{Q}-\mathrm{NH}_{2}\right)$

\section{EXPERIMENTAL}

1-Methyl-4-[4-aminostyryl]quinolinium iodide was prepared by literature method ${ }^{21,22}$ as follows: $p$-amino benzaldehyde ( $10 \mathrm{mmol})$ dissolved in a minimum amount of absolute ethanol, was added drop wise to $(10 \mathrm{mmol})$ of 1-methyl-4- 
methyl quinolinium iodide in $25 \mathrm{~mL}$ of absolute ethanol. 1.5 $\mathrm{mL}$ piperdine was added and the mixture stirred for $20 \mathrm{~h}$ at room temperature and then refluxed for $0.5 \mathrm{~h}$. The pale brown precipitate was filtered and recrystallized twice for distilled water. The melting point was determined and found to be 257$259{ }^{\circ} \mathrm{C}$, of 1-methyl-4-[4'-amino styryl]quinolinium iodide, $\left(\mathrm{Q}=\mathrm{NH}_{2}\right)($ Chart 1).

UV-visible absorption spectra measurements were carried out using Perkin- Elmer lambda 40 spectrophotometer, was matched quartz cells with pathlength of $1 \mathrm{~cm}$. The fluorescence spectra measurements were recorded on a Shimadzo RF-5000 Luminescence Spectrometer, using quartz cells and a $1 \mathrm{~cm}$ cuvette holder. Fluorescence intensities were measured at right angles to the incident light. The slight width was at narrow entrance in order to minimize the intensity of the incident light. The $\mathrm{pH}$ of the buffer solutions were checked using a Jenwary $2020 \mathrm{pH}$ meter.

The samples were prepared according to the following procedure: for the aqueous buffer solutions, $0.4 \mathrm{~mL}$ of the stock solution of $1 \times 10^{-3} \mathrm{~mol} \mathrm{dm}^{-3}\left(\mathrm{Q}=\mathrm{NH}_{2}\right)$ dye and $5 \mathrm{~mL}$ of double concentration $\mathrm{pHs}$ buffer solution was mixed in $10 \mathrm{~mL}$ volumetric flask. The mixture was dissolved and completed to $10 \mathrm{~mL}$ with double distilled water. For the micellar solution, $0.4 \mathrm{~mL}$ of the stock solution of $1 \times 10^{-3} \mathrm{~mol} \mathrm{dm}^{-3}\left(\mathrm{Q}=\mathrm{NH}_{2}\right)$ dye and $2.5 \mathrm{~mL}$ of $4 \times 10^{-2} \mathrm{~mol} \mathrm{dm}^{-3}$ sodium dodecyl sulfate was added to $5 \mathrm{~mL}$ of double concentration $\mathrm{pHs}$ buffer solution, The mixture was dissolved and completed to $10 \mathrm{~mL}$ with double distilled water. The concentration of the micelles was $1 \times 10^{-2} \mathrm{~mol} \mathrm{dm}^{-3}$, which was above the critical miscelle concentration $(\mathrm{CMC})$. The final concen-tration of $\left(\mathrm{Q}=\mathrm{NH}_{2}\right)$ dye was $4 \times 10^{-5} \mathrm{~mol} \mathrm{dm}^{-3}$ and was constant at all different aqueous and micellar solutions.

\section{RESULTS AND DISCUSSION}

Spectra in aqueous buffer solution: The optical absorption spectra of $4 \times 10^{-5} \mathrm{~mol} \mathrm{dm}^{-3}$ of $\left(\mathrm{Q}=\mathrm{NH}_{2}\right)$, in aqueous buffer solutions at different $\mathrm{pHs}$ showed that there are two forms, the quinonoid structure with mono cation on the amino group $\mathrm{Q}={ }^{+} \mathrm{NH}_{2}$ which is considered the basic form $\left(\mathrm{I}_{\mathrm{b}}\right)$ and the benzeniod structure $\mathrm{Q}-{ }^{+} \mathrm{NH}_{3}$ with double cations in which the lone pair of electrons are localized with the positive charge present on the heterocyclic nitrogen atom, which is considered the acidic form $\left(I_{a}\right)$ this indicated by Scheme-I. A typical absorption spectra of 1-methyl-4-[4'-amino styryl]quinolinium iodide, $\left(\mathrm{Q}={ }^{+} \mathrm{NH}_{2}\right)$ is shown in Fig. 1a. These spectra exhibit a well-defined isobestic point at $396 \mathrm{~nm}$, denoting the existence of an equilibrium (essentially an acid-base) between the $\mathrm{Q}=$ ${ }^{+} \mathrm{NH}_{2}$, which has an absorption maximum at $446 \mathrm{~nm}$ and the other form $\mathrm{Q}-{ }^{+} \mathrm{NH}_{3}$, which has an absorption maximum at 368 $\mathrm{nm}$ as in (Fig. 1a). This means that these dyes could be used as acid indicators, where in high $\mathrm{pH}$ giving rise $\mathrm{Q}={ }^{+} \mathrm{NH}_{2}$ and Q- ${ }^{+} \mathrm{NH}_{3}$ at low $\mathrm{pH}$.
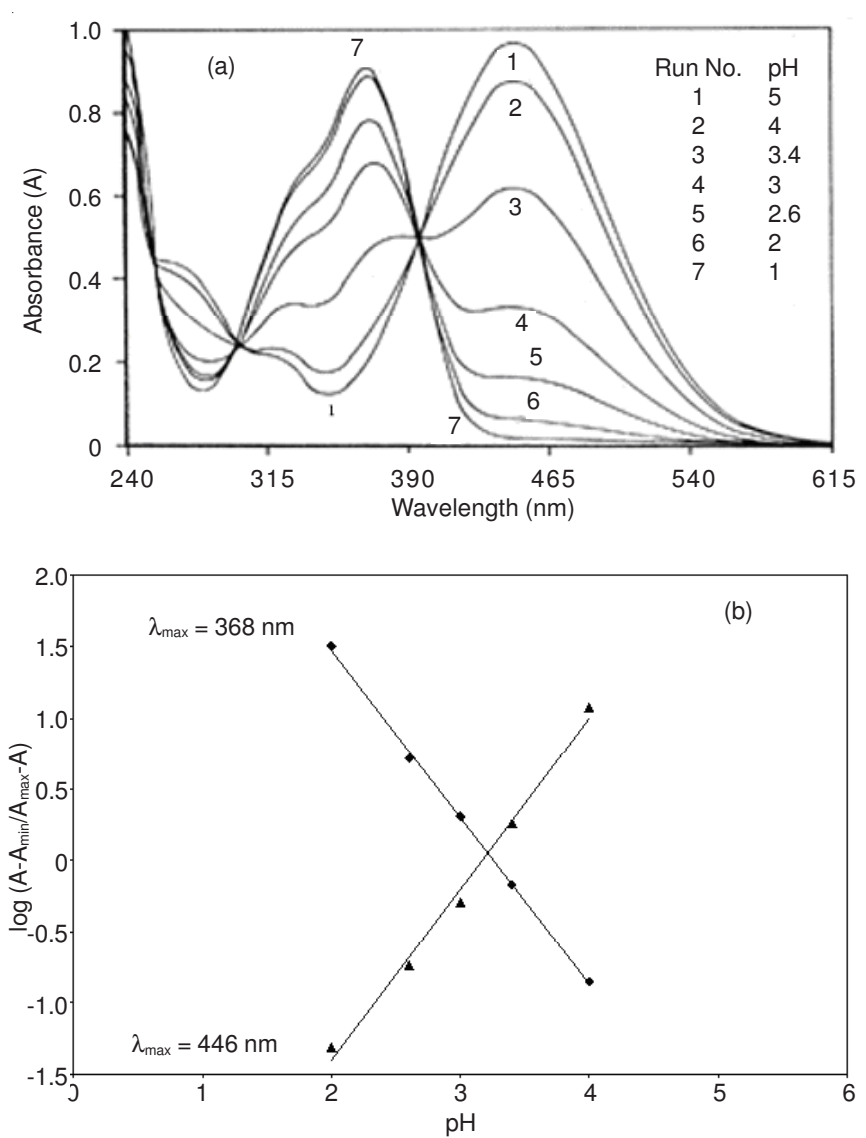

Fig. 1. (a) Absorption spectra of 1-methyl-4-[4'-aminostyryl] quinolinium iodide $\left(\mathrm{c}=4 \times 10^{-5} \mathrm{~mol} \mathrm{\textrm {dm } ^ { - 3 }}\right)$ in aqueous buffer solutions. (b) Determination of $\mathrm{pK}_{\mathrm{a}}$ of 1-methyl-4-[4'-aminostyryl]quinolinium iodide $\left(\mathrm{c}=4 \times 10^{-5} \mathrm{~mol} \mathrm{dm}^{-3}\right)$ in aqueous buffer solutions

Being these merocyanine dye similar to weak acids in their ionization (Scheme-I), its of interest to calculate their acid dissociation constant $\mathrm{pK}_{\mathrm{a}}$ values in both aqueous and micellar solutions in both ground and excited states to obtain a better understanding of its chemical and physical behavoiur in different environments of different $\mathrm{pHs}$.

The $\mathrm{pK}_{\mathrm{a}}$ value has been calculated from the following eqn. $1^{23,24}$

$$
\mathrm{pH}=\mathrm{pK}_{\mathrm{a}}+\log \frac{\left(\mathrm{A}-\mathrm{A}_{\min }\right)}{\left(\mathrm{A}_{\max }-\mathrm{A}\right)}
$$

where $A_{\max }$ is the maximum absorbance of the protonated form Q- ${ }^{+} \mathrm{NH}_{3}$ or $\mathrm{Q}={ }^{+} \mathrm{NH}_{2}$ at a given wavelength, $\mathrm{A}_{\min }$ is the minimum absorbance from the plot of $\log \left(\mathrm{A}-\mathrm{A}_{\min }\right) /\left(\mathrm{A}_{\max }-\mathrm{A}\right)$ versus $\mathrm{pH}$ is a linear relation as shown in Fig. $1 b$ the $\mathrm{pK}_{\mathrm{a}}$ was calculated as 3.24 (Table-1).

The fluorescence spectra of the same concentration of $\mathrm{Q}={ }^{+} \mathrm{NH}_{2}$ were measured in buffer solutions of different $\mathrm{pHs}$ excited at the isobestic point for the ground state $\lambda_{\text {excit. }} 396 \mathrm{~nm}$ (Fig. 2), the fluorescence spectra exhibit two bands, the first one is very broad emission band at $\lambda_{\text {em. }} 462 \mathrm{~nm}$ and the anther

TABLE-1

SPECTRAL DATA AND ACID DISSOCIATION CONSTANTS OF GROUND AND FIRST EXCITED SINGLET STATES

\begin{tabular}{lcccccccc}
\hline \multicolumn{1}{c}{ Medium } & $\mathrm{pK}_{\mathrm{a}}$ & $\lambda_{\max }$ (a) abs. & $\lambda_{\max }$ (a) flu. & $\lambda_{\max }(\mathrm{b})$ abs. & $\lambda_{\max }$ (b) flu. & $\Delta v\left(\mathrm{~cm}^{-1}\right)$ & $\mathrm{pK}_{\mathrm{a}}^{*}$ \\
\hline Aqueous buffer & 3.24 & 27174 & 21739 & 22411 & 23585 & 1459 & 0.19 \\
Aqueous micelles & 3.72 & 25176 & 21853 & 20000 & 21626 & 2702 & -1.95 \\
\hline
\end{tabular}

(a) in acid medium; (b) in alkaline medium; $\pm \mathrm{s}=0.04$. 


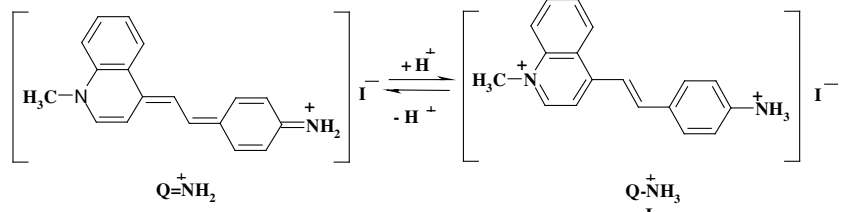

$I$

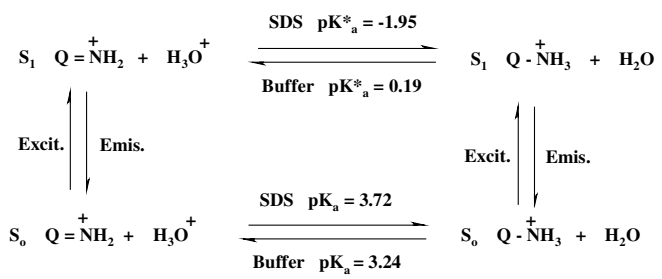

Scheme-I: Basic and acidic forms of $4 \times 10^{-5} \mathrm{~mol} \mathrm{dm}^{-3}$ of 1-methyl-4-[4'aminostyryl]quinolinium iodide, $\left(\mathrm{Q}={ }^{+} \mathrm{NH}_{2}\right) \mathrm{I}^{-}$in the grouned and excited states in aqueous and sodium dodecyl sulphate (SDS) micellar solutions

wide band at $\lambda_{\text {em. }} 524 \mathrm{~nm}$. Also a weak fluorescence intensity was observed at $\mathrm{pH}$ rang from 4 to 5 with only one band at $462 \mathrm{~nm}$. the fluorescence intensity increases in the $\mathrm{pH}$ rang $3.5-1.1$, but tends to a limiting value at $\mathrm{pH} 1.1$, with attribution at $\mathrm{pH} 2.5$.

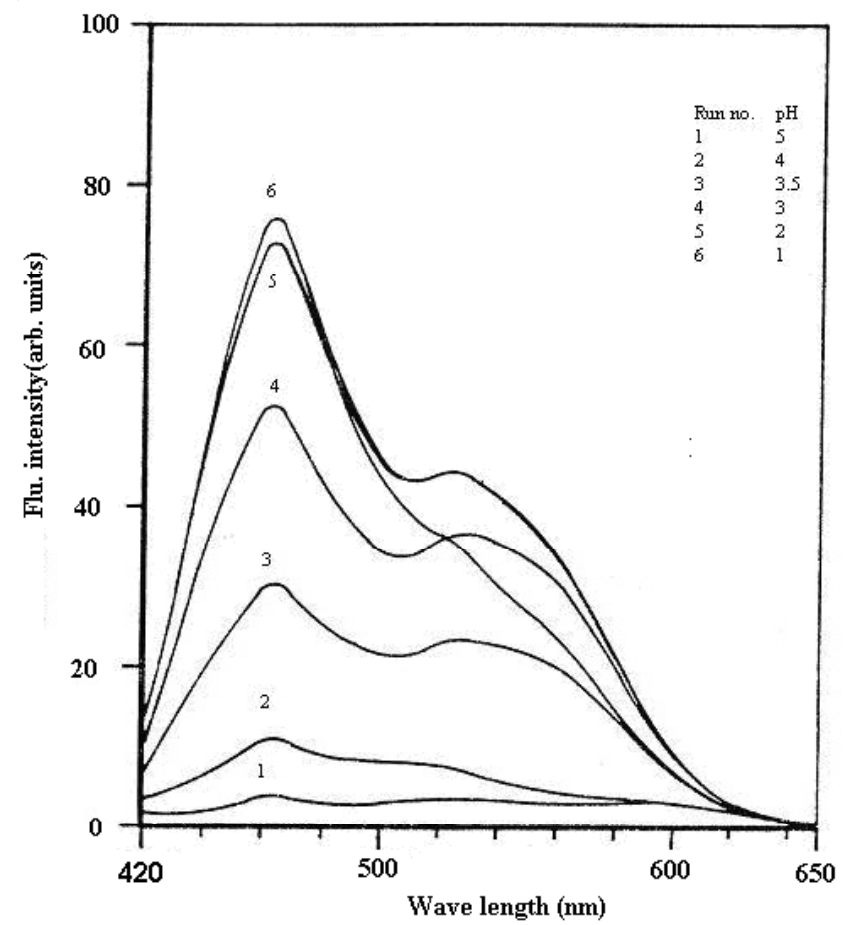

Fig. 2. Fluorescence spectra of 1-methyl-4-[4'-aminostyryl] quinolinium iodide $\left(\mathrm{c}=4 \times 10^{-5} \mathrm{~mol} \mathrm{dm}^{-3}\right)$ in aqueous buffer solutions $\left(\lambda_{\text {exc. }}=\right.$ $396 \mathrm{~nm})$

Also the fluorescence spectra of the $\mathrm{Q}={ }^{+} \mathrm{NH}_{2}$ were measured in buffer solutions of different $\mathrm{pHs}$ but was excited at another wavelength $\lambda_{\text {excit. }} 368 \mathrm{~nm}$ (Fig. 3 ). This shows that a broad emission band at wavelength $460 \mathrm{~nm}$ with $\mathrm{pH} 1.1$. The fluorescence spectra decreases with increasing the $\mathrm{pH}$, with a hypsochromic shift at $\lambda_{\text {em. }} 424 \mathrm{~nm}$ for $\mathrm{pH}$ 5. This explained as due to the interaction between the proton and the amino lone pair of electrons at lower $\mathrm{pH}$ which stabilize the benzeniod structure (Scheme-I).

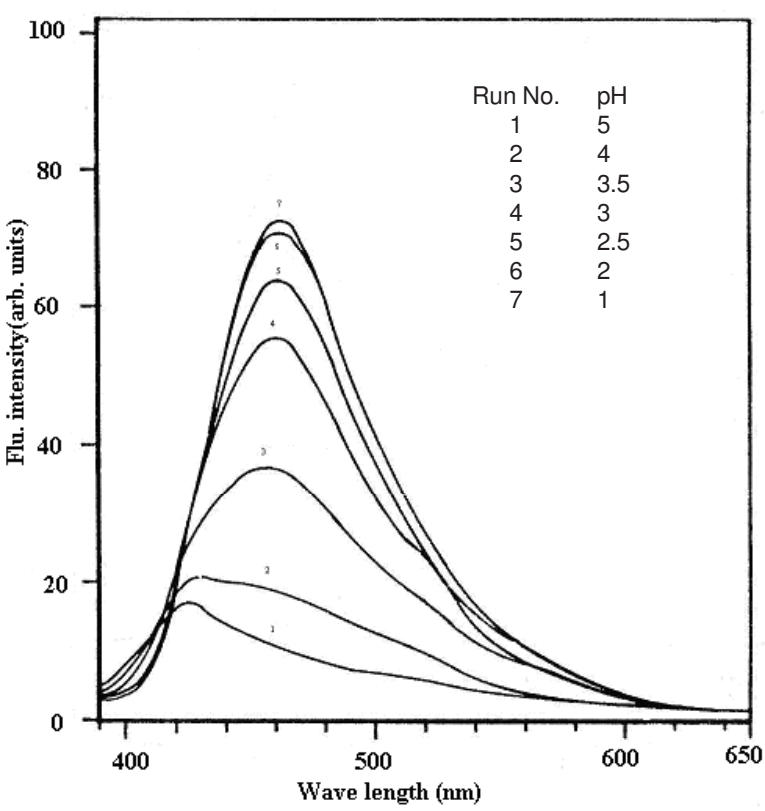

Fig. 3. Fluorescence spectra of 1-methyl-4-[4'-aminostyryl] quinolinium iodide $\left(\mathrm{c}=4 \times 10^{-5} \mathrm{~mol} \mathrm{dm}^{-3}\right)$ in aqueous buffer solutions $\left(\lambda_{\text {exc. }}=\right.$ $368 \mathrm{~nm})$

The acid dissociation constants $\mathrm{pK}^{* \prime}$ of the studied compound in excited state were calculated by utilizing the so called Forester energy-cycle ${ }^{25,26}$. According to this cycle:

$$
\mathrm{pK}^{*}=\mathrm{pK}+(\Delta \mathrm{v})\left(\frac{0.625}{\mathrm{~T}}\right)
$$

where $\mathrm{pK}$ and $\mathrm{pK}^{*}$ are the acid dissociation constants in the ground and excited states, respectively and $\Delta v$ represents the frequency difference in $\mathrm{cm}^{-1}$ between the values of the $\mathrm{O}-\mathrm{O}$ band of the electronic transition energy for the mono and dication forms existing in an equilibrium state. The results of such calculations are summarized in Table-1. Taking an average value of $\Delta v_{\mathrm{a}-\mathrm{b}}=1459 \mathrm{~cm}^{-1}$ for the absorption and fluorescence transition, the $\mathrm{pK}^{*}$ in the first excited state can be determined as 0.19 . As expected, the compound is considerably more acidic in the first excited state than in the ground state. From the electronic structure of $\mathrm{Q}={ }^{+} \mathrm{NH}_{2}$, it is expected that the quinonoid structure can be easily protonated at the aromatic amino group and the positive charge localized with lone pair of electrons which is present on the other heterocyclic nitrogen atom and increase the $-\mathrm{C}=\mathrm{C}$ - double bond character and stabilizing the benzeniod structure (Scheme-I).

Spectra in aqueous micellar solution: The absorption spectra of $\mathrm{Q}={ }^{+} \mathrm{NH}_{2}$ were carried out in aqueous micellar solution above the critical micelles concentration (CMC) at different buffer solutions. As shown in Fig. 4a, this spectrum shows that regular variation between the absorption spectra with different $\mathrm{pH}$ in the range 1.1-4.5 buffer solutions which exhibit also a well defined one isobestic point indicating the existence acid-base equilibrium, with a basic form absorption band at $500 \mathrm{~nm}$ and an acidic form absorption band at 397 $\mathrm{nm}$. The bathochromic shift observed for the acidic or basic absorption bands relative to the aqueous buffer solutions, illustrates that the $\mathrm{Q}={ }^{+} \mathrm{NH}_{2}$ due is incorporated into the micellar interface. The $\mathrm{pK}_{\mathrm{a}}$ in sodium dodecyl sulfate was calculated using eqn. 1, as shown in Fig. 4b was determined 

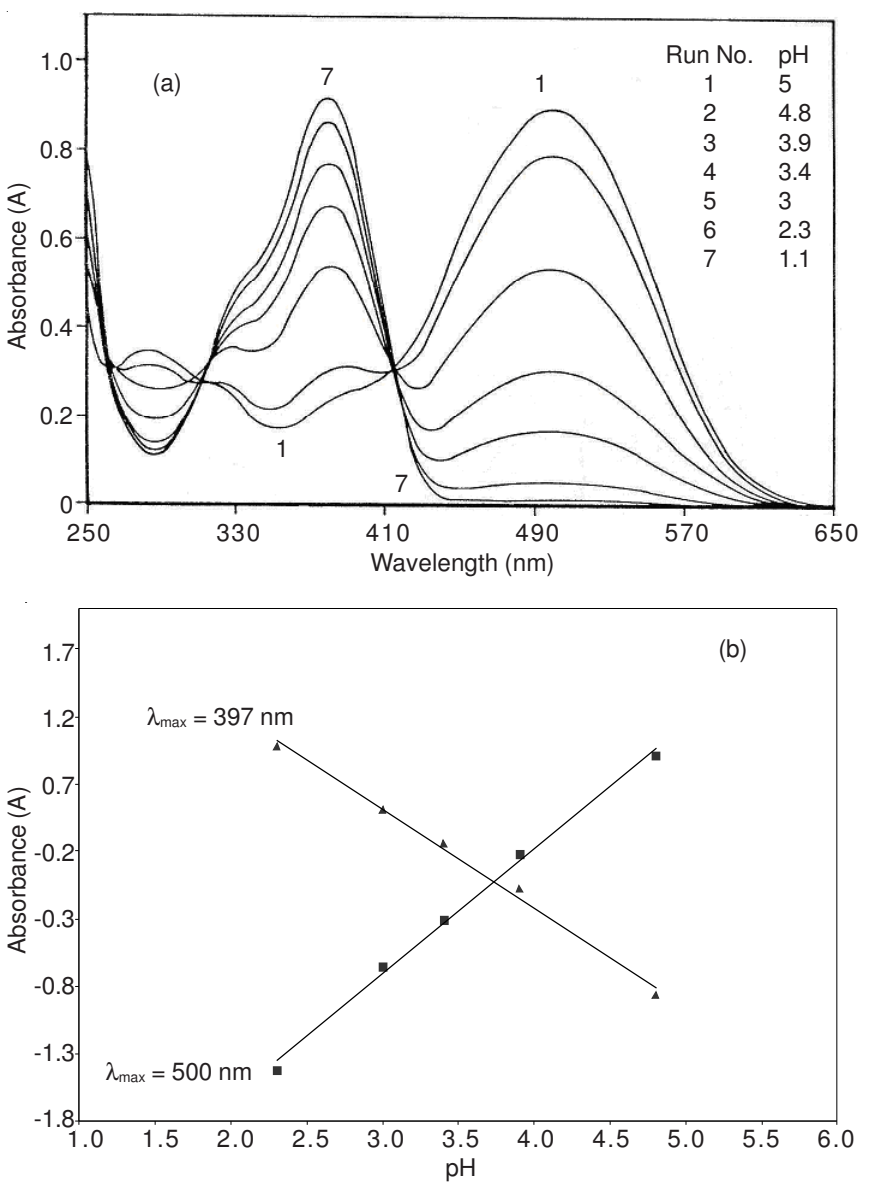

Fig. 4. (a) Absorption spectra of 1-methyl-4-[4'-aminostyryl] quinolinium iodide $\left(\mathrm{c}=4 \times 10^{-5} \mathrm{~mol} \mathrm{dm}^{-3}\right)$ in sodium dodecyl sulfate $\left(\mathrm{c}=1 \times 10^{-2}\right.$ mol $\mathrm{dm}^{-3}$ ) buffer solutions. (b) Determination of $\mathrm{pK}_{\mathrm{a}}$ value of 1methyl-4-[4'-aminostyryl] quinolinium iodide $\left(\mathrm{c}=4 \times 10^{-5} \mathrm{~mol} \mathrm{dm}^{-3}\right)$ in sodium dodecyl sulfate $\left(\mathrm{c}=1 \times 10^{-2} \mathrm{~mol} \mathrm{dm}^{-3}\right)$ buffer solutions

to be 3.72 , which is slightly higher than in aqueous solution. The slight shift in the ground state $\mathrm{pK}_{\mathrm{a}}$ of the dye in sodium dodecyl sulfate micellar solution illustrates the effect of micelles on protonation/deprotonation of the dye at different $\mathrm{pH}$ and provides as well defined difference between aqueous and micellar solution. It is of interest to explain that the slight increase of the $\mathrm{pK}_{\mathrm{a}}$ in micellar medium is due to the ability of the anionic sodium dodecyl sulfate micelles to concentrate the protons in micellar interface and slightly suppress the protonation the aromatic amino group ${ }^{27,28}$.

The excited state protolytic equilibrium was also been studied in micellar solution at $\mathrm{pH}$ ranges of 1.1-4.5 as shown in Fig. 5. The fluorescence spectra at $\lambda_{\text {exct. }}=500 \mathrm{~nm}$ shows a weak fluorescence intensity for $\mathrm{pH}=1.1$, with hypsochromic shift to $\lambda_{\text {emis. }}=579 \mathrm{~nm}$. with increasing $\mathrm{pH}$, the fluorescence intensity increases with a bathochromic shift and a broad band is obtained at $\lambda_{\text {emis. }}=614.4 \mathrm{~nm}$ also the emission spectra of the $\mathrm{Q}=\mathrm{N}^{+} \mathrm{H}_{2}$ has been studied at $\lambda_{\text {exct. }}=397 \mathrm{~nm}$. As can be seen in Fig. 6, a measurable broad band is shown at $\lambda_{\text {emis. }}=462 \mathrm{~nm}$ for $\mathrm{pH}=1.1$ and the fluorescence intensity decreased with increasing the $\mathrm{pH}$ with hypsochromic shift to $\lambda_{\text {emis. }}=457.6 \mathrm{~nm}$ at $\mathrm{pH}=4.5$. By applying Forester energy-cycle $\mathrm{e}^{25,26}$, the $\mathrm{pK}^{*}$ in a sodium dodecyl sulfate micellar system is calculated to be -1.95. Table-1 and Scheme-I shows the spectral data and the dissociation constants for the ground and first excited states.

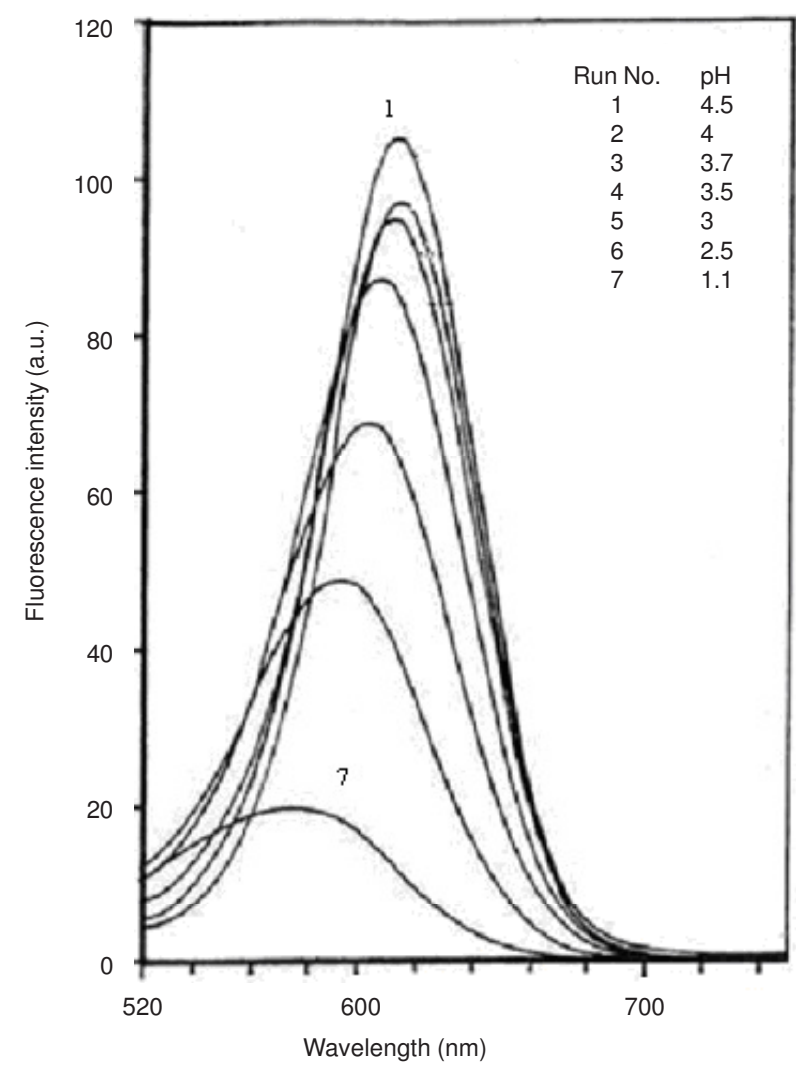

Fig. 5. Fluorescence spectra of 1-methyl-4-[4'-aminostyryl] quinolinium iodide $\left(\mathrm{c}=4 \times 10^{-5} \mathrm{~mol} \mathrm{dm}^{-3}\right)$ in sodium dodecyl sulfate $\left(\mathrm{c}=1 \times 10^{-2}\right.$ mol $\left.\mathrm{dm}^{-3}\right)$ buffer solutions. $\left(\lambda_{\text {exc. }}=500 \mathrm{~nm}\right)$

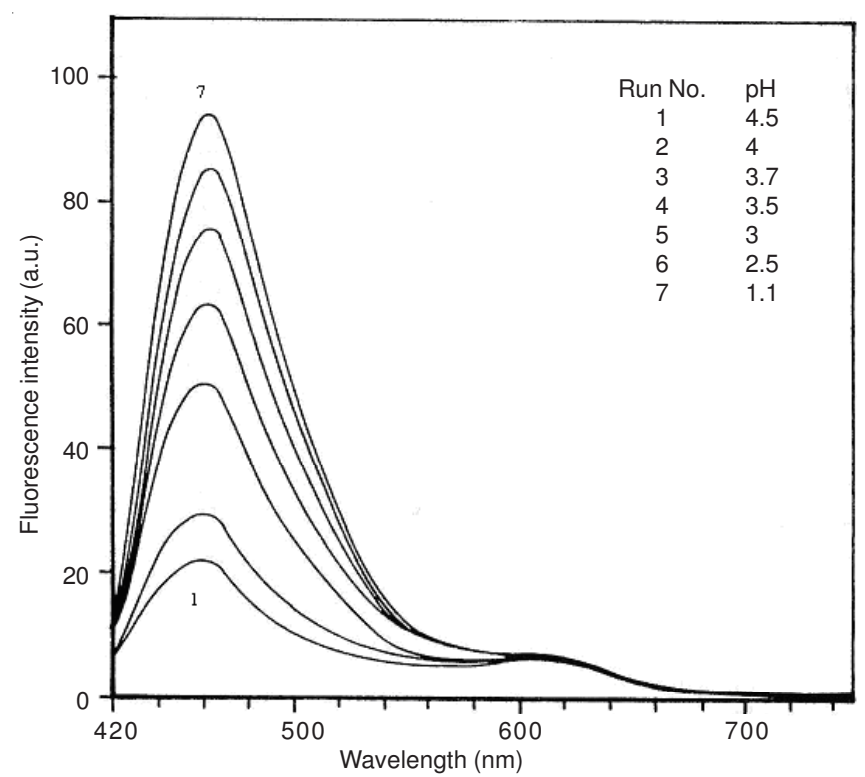

Fig. 6. Fluorescence spectra of 1-methyl-4-[4'-aminostyryl] quinolinium iodide $\left(\mathrm{c}=4 \times 10^{-5} \mathrm{~mol} \mathrm{dm}^{-3}\right)$ in sodium dodecyl sulfate $\left(\mathrm{c}=1 \times 10^{-2}\right.$ mol dm$\left.{ }^{-3}\right)$ buffer solutions $\left(\lambda_{\text {exc. }}=397 \mathrm{~nm}\right)$

These results indicated that the larger value for the $\mathrm{pK}^{*}$ of the aqueous micellar solution illustrates that $\mathrm{Q}={ }^{+} \mathrm{NH}_{2}$ first excited singlet states is a very strong acid (Table-1). This because the protolytic equilibrium in micellar solutions is influenced first by the effective dielectric constant at site of the solubilization and secondly, by the effect of the charge distribution of the counter ions in the double layer. The 
protolytic reaction in the ground state is suppressed when the concentration of the proton increases in the interface, but for the excited singlet state, the rate of protonation/deprotonation increases with the effect of diffusion, indicating that the charge effect is much larger than dielectric effect.

\section{REFERENCES}

1. E. Barni, P. Savarino and G. Viscardi, Acc. Chem. Res., 24, 98 (1991)

2. W.L. Hinze, Solution Chemistry of Surfactants, Plenum Press, New York (1979).

3. G.L. McIntire, Crit. Rev. Anal. Chem., 21, 257 (1990).

4. J.L. Beltran, R. Codony, M. Granados, A. Izquierdo and M.D. Prat, Talanta, 40, 157 (1993).

5. N. Pourreza and S. Rastegarzadeh, J. Chem. Eng. Data, 50, 206 (2005).

6. J.L. Beltran, M.D. Prat and R. Codony, Talanta, 42, 1989 (1995).

7. E. Pramaura and E. Pellezzeti, Anal. Chim. Acta, 126, 253 (1981)

8. E. Pellezzeti and E. Pramuara, Anal. Chim. Acta, 169, 1 (1985).

9. Z. Yuanqin, L. Fan, L. Xiaoyan and L. Jing, Talanta, 56, 705 (2002).

10. A.L. Underwood, Anal. Chim. Acta, 140, 89 (1982).

11. A. Abbaspour and M.A. Kamyabi, J. Chem. Eng. Data, 46, 623 (2001).

12. D. Kara and M. Alkan, Spectrochim. Acta A, 56, 2753 (2000).

13. A. Safavi and H. Abdollahi, Talanta, 53, 1001 (2001).

14. S.T. Abdel-Halim and M.K. Awad, J. Phys. Chem., 97, 3160 (1993) (and references therein).
15. W. Arden and P. Fromherz, J. Electrochem. Soc., 127, 372 (1980).

16. O. Inacker, H. Kuhun, D. Mo"bius and G. Debuch, Z. Phys. Chem., 101, 337 (1976).

17. K. Othmer, Encycl. Chem. Technol., 6, 122 (1985).

18. F. Sieber, J.L. Spivak and A. Sutctiffe, Proc. Nat. Acad. Sci. USA, 81, 7584 (1984).

19. D.J. Williams, Nonlinear Optical Properties of Organic and Polymeric Materials, ACS Symposium Series 233, American Chemical Society, Washington DC (1983).

20. A. Grinvald, R.D. Frosting, E. Lieke and R. Hildesheim, Physiol. Rev., 68, 1285 (1988).

21. M.J. Minch and S.S. Shah, J. Chem. Educ., 54, 709 (1977).

22. K.F. Donchi, G.P. Rebort, B. Temai and P.J. Derrick, Aust. J. Chem., 33, 2199 (1980).

23. J. Blanc and D.L. Ross, J. Phys. Chem., 72, 2817 (1968).

24. A.S. Shawali, E.S.S. Darwish and F.M.A. Altalbaw, Asian J. Spectrosc., 11, 115 (2007).

25. A.S. Shawali, E.S. Darwish and F.M.A. Altalbawy, Asian J. Spectrosc., 12, 113 (2008)

26. E.S. Darwish, M.A. Mosselhi, F.M. Altalbawy and H.A. Saad, Molecules, 16, 8788 (2011).

27. O.A. El-Seoud, A.M. Chinelatto and M.K. Shimizu, J. Colloid Interf. Soc., 88, 420 (1982).

28. C.A. Bunton and L. Robinson, J. Phys. Chem., 73, 4237 (1969).

29. K. Kalyanasundram, Microheterogenous Systems, Academic Press New York (1987). 